\title{
Synonymy in the Translation Equivalent Paradigms of a Standard Translation Dictionary
}

\author{
Phillip Adriaan Louw, Department of Afrikaans and Dutch, \\ University of Stellenbosch, South Africa
}

Abstract: The norm in current canonical translation dictionaries with Afrikaans and English as the treated language pair is an undiscriminated grouping of partially synonymous translation equivalents. These are separated by commas as sole markers of synonymy. Lexicographers should reject this practice and embrace the view that absolute synonyms are just as rare as absolute equivalents. In most cases members of a target language synonym paradigm will be partial synonyms demanding some form of contextual guidance in order to distinguish them from other equivalents in the paradigm.

This article will focus on the motivation for the indication of partial target language synonymy. Two particular motivations will be discussed, as well as ways in which equivalent discrimination can be implemented.

The first motivation arises from a group of problematic phenomena that effect contextual divergence between the source and target language. Stylistic and register divergence should necessitate contextual guidance. Lexicographical labels are the most frequently used discriminators, but in South African dictionaries they are applied too sparingly and inconsistently. Other possible discriminators will also be discussed.

The most problematic motivation for the indication of partial synonymy is however different equivalents for various usages of a lemma. Ways in which equivalent discrimination can be implemented in these cases, will be discussed in detail.

Lastly, it will be shown that without a new, more effective method of indicating and ordering target language synonyms, none of the major changes that are pleaded for, will bear fruit.

Keywords: ABSOLUTE SYNONYMY, CONTEXTUAL GUIDANCE, EQUIVALENT DISCRIMINATION, LEXICOGRAPHIC LABELS, PARTIAL SYNONYMY, POLYSEMY, SENSES, STANDARD TRANSLATION DICTIONARY, SYNONYMY, TARGET LANGUAGE SYNONYMS, TARGET LANGUAGE SYNONYM PARADIGM, TRANSLATION EQUIVALENT PARADIGM, USAGES OF THE LEMMA

Opsomming: Sinonimie in die vertaalekwivalentparadigmas van 'n standaard vertalende woordeboek. Die norm in die huidige kanonieke vertalende woordeboeke met Afrikaans en Engels as die behandelde taalpaar is ' $n$ ongediskrimineerde lysting van

This paper was presented at the Second International Conference of the African Association for Lexicography, held at the University of Natal, Durban, 14-16 July 1997.

Lexikos 8 (AFRLEX-reeks/series 8: 1998): 173-182 
gedeeltelik sinonieme vertaalekwivalente. Hulle word deur kommas as die enigste merkers van sinonimiteit geskei. Leksikograwe behoort hierdie praktyk te verwerp en die siening te aanvaar dat absolute sinonieme net so skaars is as absolute ekwivalente. In die meeste gevalle sal lede van 'n doeltaalsinoniemparadigma gedeeltelike sinonieme wees wat die een of ander konteksleiding benodig om hulle van die ander lede van die paradigma te onderskei.

Hierdie artikel sal op die motivering vir die aanduiding van gedeeltelike doeltaalsinonimie fokus. Twee spesifieke motiverings sal bespreek word asook wyses waarop ekwivalentdiskriminasie geïmplementeer kan word.

Die eerste motivering is die gevolg van ' $n$ groep problematiese verskynsels wat kontekstuele divergensie tussen die bron- en doeltaal veroorsaak. Stilistiese en registerdivergensie behoort konteksleiding te noodsaak. Leksikografiese etikette is die diskriminators wat die frekwentste gebrik word, maar in Suid-Afrikaanse woordeboeke word hulle te min en te inkonsekwent aangewend. Ander moontlike diskriminators sal ook bespreek word.

Die mees problematiese motivering vir die aanduiding van gedeeltelike sinonimie is egter verskillende vertaalekwivalente vir verskillende gebruike van 'n lemma. Wyses waarop ekwivalentdiskriminasie by hierdie gevalle geïmplementeer kan word, sal in detail bespreek word.

Laastens sal aangetoon word dat geen van die groot veranderings wat bepleit word, vrugte sal dra sonder 'n nuwe, meer effektiewe metode om sinonieme te merk en te orden nie.

Sleutelwoorde: ABSOLUTE SINONIMIE, BETEKENISONDERSKEIDINGS, DOELTAALSINONIEME, DOELTAALSINONIEMPARADIGMA, EKWIVALENTDISKRIMINASIE, GEBRUIKE VAN DIE LEMMA, GEDEELTELIKE SINONIMIE, KONTEKSLEIDING, LEKSIKOGRAFIESE ETIKETTE, POLISEMIE, STANDAARD VERTALENDE WOORDEBOEK, SINONIMIE, VERTAALEKWIVALENTPARADIGMA

Standard translation dictionaries with Afrikaans and English as treated language pair present the South African lexicographer with a unique challenge. Within the current dictionary culture and corresponding market, there is scarcely room for dictionaries aimed at a single language group. The demand is for a standard bilingual bidirectional translation dictionary addressing two language groups. Such a dictionary must be a practically viable linguistic aid as well as a cultural product that reflects the changing faces of the standard varieties of Afrikaans and English.

The defiance of the traditional typological plea for a single user addressing (following Ščerba's vital distinction between active (production, encoding) and passive (receptive, decoding) dictionaries), necessitates a fresh perspective on all the structures of the dictionary. Its most profound implications are however on a microstructural level. Current representatives in this class, such as Tweetalige Woordeboek / Bilingual Dictionary (henceforth BD) and Groot Woordeboek / Major Dictionary (henceforth MD) have not met these challenges adequately. Louw and Gouws (1996) have shown that innovative changes to the addressing procedures in these dictionaries can help the microstructure to become an effective key to communicative equivalence, as it should be. Yet the practical nature of such changes (which must, on a microstructural level, be manifested in con- 
sistently applied systems of discrimination) has not been fully addressed. The implications for the treatment of some of the most salient lexicographical hurdles e.g. homonymy, polysemy and synonymy will require illumination. Synonymy, perhaps the most problematic and badly dealt with hurdle, will be discussed in this article.

\section{Source language polysemy vs. target language synonymy}

It is essential that any lexicographer should, as part of the translation dictionary's organisation, make a demarcation between source language polysemy and target language synonymy and make this demarcation accessible to the dictionary's users. The current system dictates that semicolons separate single translation equivalents or different target language synonym paradigms that can replace a lexical item in its different senses. Commas separate different target language synonyms within a given target language synonym paradigm or list of synonyms. This system is often confusing to many users who struggle to gauge this creative appropriation of everyday punctuation. Furthermore both meaning (especially sense) discrimination and equivalent discrimination that can show up contextual differences between target language synonyms, is applied too sparingly and inconsistently.

The result is that a distinction that should be crystal clear is muddled instead. Long lists of equivalents are given and the less competent user has little chance of knowing the significance of conventions (which are not explained in the explanatory introduction). The user also has little chance of making the right choice. It is small wonder that Kromann et al. (1991: 2724) commented in particular on the undiscriminated listing of quasi synonyms by calling this "one of the ancient and deadly sins of translation lexicography in bidirectional dictionaries".

\section{Target language synonymy}

Whereas discrimination between senses can be relatively easily maintained by means of a combination of sense discrimination and translation complements, equivalent discrimination in target language synonym paradigms is a more difficult matter. In order to come to a conclusion about the demands made on a lexicographer, target language synonymy and especially partial synonymy will be discussed in this paper. Examples from Groot Woordeboek / Major Dictionary, one of the bilingual desk dictionaries currently filling the gap the absence of a standard translation dictionary has left, will be examined. Firstly, reasons for the listing of target language synonyms will be surveyed.

\section{Reasons for the listing of target language synonyms}

Martin (1967: 156) gives two reasons for the listing of synonymous translation equivalents. Firstly a dictionary must "suggest to the translator a range of choi- 
ces". Bogaards (1994: 613) expounds on this point of view by stating that a range of target language synonyms should be given, so that the user can be sure of finding "the one element that best fits the context". It is especially the failure of lexicographers of translation dictionaries to meet the practical requirements of this aim that has been severely criticised by metalexicographers and translators. See for example Martins' (1967: 156) own criticism, "sometimes the uncritical heaping of near synonyms is simply an evasion of responsibility on the part of the dictionary maker: unable to (or too little informed) to make up his own mind, he shifts the burden of choice to the user of the dictionary". If a general standard translation dictionary takes this procedure too far, it could waste valuable space. The lexicographer has to make sure that every synonym given is truly a functional translation equivalent for the lemma and make sure that the context of equivalence is clear.

Secondly, Martin states that "target language synonyms must be listed in order to give a clearer picture of the semantic spectrum of every item". His definition might however lead to a faulty assumption that there is necessarily some semantic difference between target language synonyms. This is only true though if the target language item is itself polysemous. Translation equivalents listed in a target language synonym paradigm (even if they themselves are polysemous lexical items), do not represent different senses of the lemma and can therefore not "give a clearer picture of a semantic spectrum of the lemma". Target language synonyms must display the full usage and contextual spectrum of the lemma. This approach necessitates a different view of synonymy as a whole, with the concept of partial synonymy as the point of focus.

\section{Absolute vs. partial synonymy}

In this article the view that there are few if any absolute synonyms in a language, is supported. On this point see Al-Kasimi (1977: 63) and Louw and Nida (1988: xv). The term partial synonymy is then used to show that contextual differences do exist between target language synonyms. Within the boundaries of this model, I shall focus on two of the possible motivations for the indication of partial synonymy in a target language synonym paradigm. The status quo in MD will be critically analysed and suggestions will be made on how to deal with this issue more adequately.

\section{Contextual differences that require labelling}

The first motivation for the indication of partial synonymy in a target language synonym paradigm still implies a relation of lexical divergence between the lemma and the target language forms. The lemma or specific sense of the lemma can be replaced by different translation equivalents, because there are two or more contextual nuances implicit in the source language form. It is even 
possible that the target language may have a separate lexical item for each of these nuances.

Examples of such divergence which may require labelling (or even more contextual guidance) are stylistic and register divergence. The target language synonyms are therefore semantically equivalent to each other, but differ in style or register. Ideally they reflect a stylistic or register variation that is not implicit in the source language item, because this lemma is a neutral form that defies contextual boundaries and can accordingly be used in different registers and stylistic contexts. In translation dictionaries with Afrikaans and English as treated language pair, for example, this is however not always the case.

The ideal is approached in a case such as pa in the Afrikaans-English side of MD. Pa gets four synonymous translation equivalents, pa, father, dad and daddy. Each of these can be used in a slightly different context. The variation exists on the level of style (e.g. father vs. dad ) and on the level of register (e.g. adult language in father vs. child language in daddy). MD rightly lists these translation equivalents as synonyms. The user here has to deal with a source language lexical item, pa, that can be used in different stylistic contexts and registers and has to make the right choice of equivalent to fit the source language context. The target language is so nuanced that various words can be used in this stylistic and register spectrum. The source language does however also contain several words (e.g. vader, pappa, pappie, outop, etc.) to cover this spectrum. The neutral term (in this case pa) can be translated with target language forms that belong to different styles and registers, but the more marked lexical items should be translated only with target language forms that are equivalent in style and register. This is not always the case, as will be shown in the discussion of pseudodivergence.

Where MD's information transfer also fails is in the clarification of the context of equivalence. No contextual guidance is given in the above-mentioned target language synonym paradigm. Gouws (1989: 204) discusses the usefulness of stylistic and other labels in detail. In this case, labels could have provided the necessary equivalent discrimination. Neither Tweetalige Woordeboek/ Bilingual Dictionary nor MD have a consistently applied system of stylistic labels with the translation equivalent as address. This is a weakness that depreciates the value of both these dictionaries as tools of empowerment in the search for communicative equivalence.

The same lack of consistency is found when there are differences of register caused by jargon. Afrikaans does not have an accessible medical term as partial synonym for pitsweer. As a result the lemma pitsweer in MD is given two synonymous translation equivalents: furuncle and boil. No label is however given to distinguish furuncle as a medical term from the more generally used term boil. For source and target language speakers alike, this procedure should be unacceptable. A consistently applied system of both lemmatically addressed and nonlemmatically addressed labels should be a priority in a truly innovative standard translation dictionary. 


\section{Pseudodivergence}

Furthermore, should communicative equivalence be the primary aim of a standard translation dictionary, only truly functional equivalents should be given. As pointed out before, this is often not the case. In $\mathrm{MD}$, for example, translation equivalents are given that are not functional equivalents of the lemma. In the article with the lemma urinate, the lexical item fluit (which also means "whistle" in Afrikaans) is presented as an unmarked translation equivalent and therefore as an absolute synonym for urineer. It is obvious though that fluit is a marked lexical item, which if chosen in any formal context, could have embarrassing results for any decoding or re-encoding English-speaking dictionary user not fully proficient in Afrikaans. The situation is even worse in a case such as the treatment of bullshit in MD, where a mixed presentation of vulgar and standard terms in one target language synonym paradigm can cause problems for any user.

bull: shit, (vulg.), stront, kak, onsin, nonsies, nonsens ...

Far more care should be taken when dealing with sensitive lexical items (especially profanities, sexist language, etc.) and even standard language forms that refer to sensitive issues.

\section{Further possible study}

The discussion of this motivation for the indication of partial synonymy has focused on stylistic and register variation. Dialectic, temporal and other differences have not been discussed but should form part of any detailed future study dealing with partial target language synonymy. A study of this magnitude would also have to include an examination of the second motivation: different translation equivalents for different usages of the lemma.

\section{Different translation equivalents for different usages of a lemma}

From within lexical semantics there has always been a special effort to determine the precise meaning of each specific lexical item. This has led to a wellreasoned distinction between the senses (referring to semantic nuancing) of a lexical item as opposed to the usages thereof. These usages encompass contributing values from the extralinguistic context. Differences exist that cannot be shown up by means of a strict semantic analysis of the lexical item.

This distinction is well cacered for in the Afrikaans and English monolingual lexicography. Whereas polysemy is indicated by means of a numerical, article internal system, different usages are given different letters of the alphabet as indicators. In cases where these usages fall within the scope of specific 
enses, the letters combine with the numerical sense indicators.

Even though not consistently applied in monolingual dictionaries (possibly because of lack of space), this system is very relevant to translation dictionaries. The anisomorphism of languages often leads to a situation where a certain language has one item with different usages, but another language has a number of lexical items to display the same range of factors contributing from the extralinguistic context. These lexical items are usually presented as target language synonyms in a translation equivalent paradigm.

MD follows this principle in its treatment of the lemma tjank. Among others it lists yelp, howl and whine as synonymous translation equivalents. The differences between these items can rightly be described as subtle contextual nuances that reflect the different usages of tjank. MD yet again does not explicate the context by means of additional contextual guidance to its users. Consequently, this entry is of little use to source and target language users alike. The situation is worsened by the inclusion of blub and bleat in the target language synonym paradigm, when they obviously represent separate senses and not separate usages of the lemma.

The veiling of information created by the undiscriminated heaping of yelp, howl and whine can easily be avoided by giving contextual guidance to lead the user to the equivalent he/she needs. Only two types of discrimination that illuminate the context are discussed here. Firstly, a discriminator akin to the source language entries used as sense discrimination can be employed. This must preferably not be a full sentence, but ideally a phrase or a word that precedes the translation equivalent. If possible, this discriminator must also be presented in a different typeface or -size to the lemma or the translation equivalent. This will make the inner search route easier by countering confusion in the user's mind with regard to the inner access structure of the dictionary. In the article with the lemma tjank, for example, these discriminators could be used. "kort en hard " can be inserted in front of yelp, "lank en hard " in front of howl and "lank en saggies $\sim$ " in front of whine. The tilde represents the lemma. With these discriminators the necessary information is correctly given early on in the source language user's inner search route.

These entries have the lemma as primary address. They help to guide the dictionary user towards the correct usage of the lemma, thereby facilitating the choice of the correct equivalent. Yet the addressing structure is more complex than it originally appears to be. The discriminator itself is the primary address of the translation equivalent, which is then connected to the lemma only by means of a secondary lemmatic addressing procedure. Though primarily addressed to the lemma the discriminator, because of its interposition, provides valuable equivalent discrimination. The source language speaker therefore gets the best of both the source and the target language worlds.

This type of discrimination is particularly valuable in cases where one translation equivalent encompasses two or more of the lemma's usages. The discriminators can then for example be separated by "en"/"and". If the 
lexicographer thinks a clearer distinction should be made, the translation equivalent can be listed more than once with separate discriminators. In most cases, however, this type of relisting which clashes with Haas's (1967: 46) "compactness desideratum", should not be necessary. See the treatment of kring in MD. Circle can act as translation equivalent for the lemma in several of its senses and source language usages. A possible source language usage discriminator that precedes circle could be: $\mathbf{a}$ en $\mathbf{b}$ "sirkelvormige lyn" en "persone, diere wat ' $n$ sirkel vorm". The phrases used here are taken from the HAT (Odendal 1994: 584).

The first type of discriminator targets the source language user. The needs of the mother tongue speaker of the target language should, however, not be ignored. A system of context words or phrases in the target language acting as translation complements can be useful equivalent discrimination. They can be used either in isolation, or in combination with the previously mentioned source language discriminators. The context word or phrase is then addressed directly to the translation equivalent and the translation equivalent to either the lemma or to the preceding source language discriminator.

This system is introduced in the treatment of the lemma die in MD. The translation equivalent sneuwel is discriminated from its synonymous partner doodgaan by means of the context phrase (op slagveld). In this instance two usages of the lemma are lexicalised as two items in the target language. The first of these two items, doodgaan, is entered unmarked, because of its status as the primary equivalent. The omission of contextual guidance at the primary equivalent can only be practised within the South African context where a reasonably high level of bilingualism exists. The lexicographer of any future standard translation dictionary must keep the extent of his/her target user group carefully in mind, before this practice can be accepted uncritically. The omission of contextual guidance cannot benefit less competent bilingual users, but in opposition to this, valuable space could be saved by this omission.

However, the greatest problem in this dictionary seems to be the lack of consistency in the application of a workable system. Context words and phrases highlight usage divergence only sporadically in MD. The omission of guidance on usage creates problems in the case of sexually sensitive terms. If one proceeds from the politically and linguistically more correct presupposition that gender differences implicit to a single lexical item are usages rather than senses of that particular item, a lemma such as teacher should, for example, be given three equivalents, each with a separate discriminator: onderwyser (neutraal t.o.v. geslag), onderwyseres (vroulik) and onderwyser (manlik). The order in which these equivalents are listed, is based on intuitive frequency and is therefore not a final one. In MD the given equivalent onderwyser(es) receives no contextual guidance and does not reflect the usage trilogy. Furthermore, the use of brackets is never explained in the introduction or user's guide. As another example of this inadequacy, see MD's treatment of Parisian, where a similar usage trilogy exists. 
The discussion of two types of discrimination should not at all be seen as an attempt at exhausting the field of study. Lexicographical examples, longer definientia, illustrations and menus are all options. Their functional value as discriminators between equivalents replacing different usages of a lemma still needs to be explored. The study of discrimination within target language synonym paradigms is still very new.

\section{Indication and ordering}

The discussion of different usages of the lemma raised another crucial issue besides discrimination. It is also necessary to find a good, consistently applied system of indicating meaning and contextual relationships in the microstructure. It is unacceptable, for example, to list near-absolute synonyms together with translation equivalents for the different usages of the lemma and separate them all by means of commas. Equivalents for different usages of the lemma lie on the border of partial synonymy because they cover large contextual differences not traditionally regarded to be of a semantic nature. In fact it is debatable whether one should for example call howl, yelp and whine synonyms at all, as treated in MD. The best approach seems to be the appropriation of the letter system from monolingual dictionaries along with the numerical system denoting senses. The letters will create new units with nonsemantic boundaries within which finer distinctions within the category of partial synonymy can be made. Semicolons can then for example be used to separate synonyms that display differences that can be shown up by means of labels. Commas can separate near-absolute synonyms. The reinterpretation of synonymy as a contextual instead of a strictly semantic phenomenon precludes the possibility of absolute synonymy in Afrikaans and English. No provision should be made for absolute synonyms. It is important that the lexicographer explains these changes made to the inner access structure as well as the changes to the article structure in an introduction or user's guide.

Within this system, equivalents will have to be ordered in structured sets according to empirical methods. All additional information aimed at the equivalents will have to be integrated within these sets or units. As has been shown elsewhere in the world, this is the only way to achieve functional equivalence and facilitate communicative success:

\section{Conclusion}

In this article only two motivations for the listing of partial synonyms were discussed. A better treatment of these and of issues such as target language polysemy is needed in future dictionaries. I have focused on the need for equivalent discrimination in the target language synonym paradigms. The lack of consistently applied systems of discrimination is one of the contributing factors 
to the often failing information transfer in BD and MD. There is also a need to find better methods of ordering and indicating relations within target language synonym paradigms.

More careful attention must in future be paid to making the nature and extent of partial synonymy clear to the user. This plays an important part in an innovative approach that can make the microstructure a truly effective key to unlocking communicative equivalence.

\section{Bibliography}

\section{A. Dictionaries}

Bosman, D.B. et al. 1984". Tweetalige Woordeboek/ Bilingual Dictionary. Cape Town: Tafelberg. Kritzinger, M.S.B. et al. $1986^{13}$. Groot Woordeboek/Major Dictionary. Pretoria: I.L. van Schaik. Louw, J.P. and E. Nida. 1988. Greek-English Lexicon of the New Testament Based on Semantic Domains. Vol. 1. New York: United Bible Societies.

Odendal, F.F. 1994³. Verklarende Handwoordeboek van die Afrikaanse Taal (HAT). Doomfontein: Perskor.

\section{B. Other sources}

Al-Kasimi, A.M. 1977. Linguistics and Bilingual Dictionaries. Leyden: E.J. Brill.

Bogaards, P. 1994. Synonymy and Bilingual Lexicography. Martin, W. et al. (Eds.). 1994: 612-617. Gouws, R.H. 1989. Leksikografie. Cape Town: Academica.

Haas, M. 1967. What Belongs in a Bilingual Dictionary? Householder, F.W. en Sol Saporta (Eds.). 1967: 45-50.

Hausmann, Franz J. et al. (Eds.). 1989-1991. Wörterbücher. Ein internationales Handbuch zur Lexikographie/Dictionaries. An International Encyclopedia of Lexicography/Dictionnaires. Encyclopédie internationale de lexicographie. Berlin: Walter de Gruyter.

Householder, F.W. and Sol Saporta (Eds.). 1967. Problems in Lexicography. Bloomington: Indiana University.

Kromann, Hans-Peder, Theis Riiber and Poul Rosbach. 1991. Principles of Bilingual Lexicography. Hausmann, Franz J. et al. 1989-1991: 2711-2729.

Louw, P.A. and R.H. Gouws. 1996. Lemmatiese en nielemmatiese adressering in Afrikaanse vertalende woordeboeke. South African Journal of Linguistics 14(3): 92-100, August 1996.

Martin, S.F. 1967. Selection and Presentation of Ready Equivalents in a Translation Dictionary. Householder, F.W. en Sol Saporta (Eds.). 1967: 153-159.

Martin, W. et al. (Eds.). 1994. Euralex 1994 Proceedings. Amsterdam: Free University Press.

Šcerba, L.V. 1995. Towards a General Theory of Lexicography. International Journal of Lexicography 8(4): 314-350, Winter 1995. 